\title{
Dampak Pemberdayaan Perempuan terhadap Perilaku Ekonomi Rumah Tangga (Studi Kasus pada Kelompok Wanita Tani di Kota Prabumulih, Sumatra Selatan)
}

\author{
The Impact of Women's Empowerment on Household Economic Behavior (Case Study of \\ Farmer Women's Group in Prabumulih, South Sumatra)
}

\author{
Rona Anggrainie $^{1 *}$, Siska Alfiati ${ }^{1}$ \\ ${ }^{1}$ STIE Prabumulih, Kota Prabumulih, Sumatra Selatan 31122 \\ ${ }^{*}$ Penulis untuk korespondensi: ronanggrainie@gmail.com \\ (diterima 18 September 2019, disetujui 14 Oktober 2019)
}

Sitasi: Anggrainie R, Alfiati S. 2019. The impact of women's empowerment on household economic behavior (case study of farmer women's group in Prabumulih, South Sumatra). Jurnal Lahan Suboptimal: Journal of Suboptimal Lands. 8(2): 192-201.

\begin{abstract}
This study aimed to analyze the level of family welfare as a result of the empowerment of women through the Women Farmers Group. The analytical method was carried out descriptively by tabulating data, then analyzed by comparing with the reference level of the prosperous family and its indicators based on the conditions set by the BKKBN. To analyze the impact of women's empowerment on household economic behavior, it was carried out using multiple linear regression analysis. Sampling was carried out by a simple random sampling method of 60 housewives who were members of the Wanita Tani Group. The results of this study indicated that when viewed from the indicators set by the BKKBN, the majority of Women Farmers Households were in the Prosperous Family II category. Simultaneously, the variable intensity of the participants, the number of family members, the age of the mother, the level of education of the mother had a significant effect on the level of income, maternal work time, and household consumption in the City of Prabumulih. But partially, the intensity of the participants had a significant effect on time spent working and household expenses, while on household income was not significant.
\end{abstract}

Keywords: consumption, income, work time

\begin{abstract}
ABSTRAK
Penelitian ini bertujuan untuk menganalisis tingkat kesejahteraan keluarga sebagai dampak pemberdayaan perempuan melalui Kelompok Wanita Tani. Metode analisis dilakukan secara deskriptif dengan tabulasi data, selanjutnya dianalisis dengan membandingkan dengan acuan tingkat keluarga sejahtera beserta indikatornya berdasarkan syarat yang ditetapan BKKBN. Untuk menganalisis dampak pemberdayaan perempuan terhadap perilaku ekonomi rumah tangga, dilakukan dengan menggunakan analisis regresi linier berganda. Pengambilan sampel dilakukan dengan metode simple random sampling sebanyak $60 \mathrm{ibu}$ rumah tangga anggota Kelompok Wanita Tani. Hasil penelitian ini menunjukkan bahwa jika dilihat dari indikator yang ditetapkan oleh BKKBN, rumah tangga Kelompok Wanita Tani sebagian besar berada pada kategori Keluarga Sejahtera II.
\end{abstract}


Secara bersamaan, variabel intensitas peserta, jumlah anggota keluarga, umur ibu, tingkat pendidikan ibu berpengaruh nyata terhadap tingkat pendapatan, curahwan waktu kerja ibu, dan konsumsi rumah tangga di Kota Prabumulih. Tetapi secara parsial, intensitas peserta berpengaruh signifikan pada curahan waktu kerja dan pengeluaran rumah tangga, sedangkan pada pendapatan rumah tangga tidak signifikan.

Kata kunci: curahan waktu kerja, pendapatan, pengeluaran rumah tangga

\section{PENDAHULUAN}

Upaya pemberdayaan perempuan adalah bagian integral dari upaya pembangunan nasional. Sehingga merupakan upaya yang berkelanjutan sesuai dengan dinamika perubahan sosial budaya ataupun ekonomi yang berlangsung secara cepat dalam era global saat ini. Sasaran program pemberdayaan perempuan diarahkan unruk mengembangkan berbagai potensi yang ada pada perempuan yang memungkinkan untuk memanfaatkan hal dan kesempatan yang sama dengan laki-laki, serta untuk memanfaatkan hak dan kesempatan yang sama terhadap sumber daya pembangunan (Sulistyani, 2014)

Menurut Nakajima dalam Kusnadi (2005), mempelajari sektor pertanian di negara sedang berkembang seperti di Indonesia, menyangkut karakteristik tiga aspek penting, yaitu (1) karaktersistik teknologi produksi pertanian,

karakteristik rumah tangga petani (farm household) sebagai satu unit ekonomi, dan (3) karakteristik produk-produk pertanian sebagai komoditas. Aspek rumah tangga petani merupakan aspek penting untuk dipelajari mengingat sebagian besar produk sektor pertanian di Indonesia disumbang oleh kegiatan usahatani rumah tangga.

Pertanian merupakan sumber mata pencarian utama bagi masyarakat Prabumulih. Akan tetapi dengan berbagai keterbatasan para petani sebagai pengelola kegiatan pertanian tersebut, bidang pertanian belum menjadi sumber utama pendapatan daerah di Prabumulih (Anggrainie, 2011). Jika dilihat berdasarkan data Badan Pusat Statistik pada Prabumulih dalam Angka (2017), terlihat dari penggunaan lahan seluas $71,24 \%$, pertanian secara keseluruhan hanya memberi sumbangan sebesar $8,37 \%$ dari total pendapatan daerah.

Untuk itu perlu adanya peningkatan kualitas petani untuk dapat meningkatkan peran sektor pertanian. Salah satu langkah konkrit yang telah dilakukan adalah dengan mengaktifkan kegiatan kelompok tani. Yang salah satu bagiannya adalah kelompok wanita tani (Warga, 2016). Hal ini didukung oleh hasil penelitian yang dilakukan Fatmawati (2018), yang menyatakan bahwa kelompok wanita tani berperan sebagai wadah untuk meningkatkan pendapatan keluarga melalui kegiatan pengolahan hasil pertanian dan pemanfaatan lahan pekarangan dalam meningkatkan produktivitas keluarga.

Kegiatan KWT sebagai bagian dari pemberdayaan ekonomi perempuan yang dilaksanakan pada akhirnya diharapkan mampu meningkatkan tingkat kesejahteraan rumah tangga (Minarni, 2017). Namun dalam realisasinya, rumah tangga itu sendiri memiliki peran ganda dalam kegiatan ekonomi, disatu sisi sebagai produsen, sebagai tenaga kerja, dan juga sebagai konsumen. Hal ini menjadi menarik untuk dianalisis bagaimana perilaku rumah tangga sebagai pelaku ekonomi terkait dengan kegiatan pemberdayaan perempuan melalui KWT (Kuncoro et al., 2016). Perilaku produsen dengan tujuan memaksimalkan sumber daya yang ada untuk menghasilkan barang dan jasa, perilaku sebagai kosumen dengan memanfaatkan barang dan jasa untuk kebutuhan rumah tangga, serta sebagai penyedia tenaga kerja menjadikan rumah tangga sebagai contoh kompleks sebagai pelaku ekonomi dengan perilakuperilakunya (Anggrainie, 2014).

Dalam penelitian yang dilakukan oleh Husin (2011), menyarankan agar peneliti selanjutnya menelaah tentang alokasi waktu 
rumah tangga petani karet, selain pada kegiatan usahatani. Berdasarkan latar belakang tersebut di atas, maka tujuan dari penelitian ini untuk menganalisis tingkat pendapatan rumah tangga sebagai dampak pemberdayaan ekonomi perempuan di Kota Prabumulih, dan menganalisis dampak pemberdayaan ekonomi perempuan terhadap perilaku ekonomi rumah tangga di Kota Prabumulih Bagian pendahuluan berisi latar belakang disertai pengacuan pada pustaka-pustaka primer penting terkait dan diakhiri dengan paragraf tujuan penelitian.

\section{BAHAN DAN METODE}

Metode penelitian yang digunakan dalam penelitian ini adalah metode survey. Dengan data yang akan dikumpulkan berupa data primer dan sekunder. Dalam Sugiyono (2013), untuk melihat dampak pemberdayaan ekonomi perempuan dalam hal ini pada kelompok wanita tani, peneliti membandingkan perilaku ekonomi rumah tangga anggota kelompok wanita tani dengan perilaku ekonomi rumah tangga bukan anggota kelompok wanita tani. Pemilihan sampel dalam penelitian ini dilakukan dengan cara purposive sampling sebanyak 60 rumah tangga di Prabumulih.

$$
\text { Untuk mengukur tingkat }
$$

kesejahteraan rumah tangga petani terdapat beberapa cara yang dapat dilakukan, seperti menggunakan metode Good Servise Ratio (GSR), dengan membandingkan tingkat pengeluaran pangan dengan pengeluaran non pangan seperti yang dilakukan oleh Rohmah et al. (2014) dalam penelitiannya. Adapun untuk menganalisis tingkat kesejahteraan keluarga peserta Kelompok Wanita Tani, peneliti menggunakan indikator keluarga sejahtera yang ditetapkan oleh BKKBN berdasarkan Undang-Undang Republik Indonesia No. 52 Tahun 2009 tentang perkembangan Kependudukan dan Pengembangan keluarga, dengan indikator (Tabel 1).

Untuk melihat dampak pemberdayaan ekonomi perempuan dalam kelompok wanita tani terhadap perilaku ekonomi rumah tangga, peneliti menggunakan regresi linear berganda,dengan tiga pendekatan, yaitu dari pendapatan rumah tangga, curahan waktu kerja wanita dan konsumsi rumah tangga.

Model regresi linier berganda yang digunakan untuk mengetahui faktor-faktor yang mempengaruhi pendapatan rumah tangga :

$\dot{Y}_{1}=a+b_{1} X_{1}+b_{2} X_{2}+b_{3} X_{3}+b_{4} X_{4}+\mu$

Dimana :

$\hat{Y}_{1}=$ Total pendapatan rumah tangga

$\mathrm{a}=$ Intercept atau konstanta

$\mathrm{b}_{1}, \mathrm{~b}_{2}, \mathrm{~b}_{3}, \mathrm{~b}_{4}=$ Parameter koefisien regresi

$\mathrm{X}_{1}=$ Intensitas peserta

$\mathrm{X}_{2}=$ Jumlah anggota keluarga

$\mathrm{X}_{3}=$ Umur ibu rumah tangga

$\mathrm{X}_{4}=$ Tingkat pendidikan ibu rumah tangga

$\mu=$ error term (koefisien error)

Hipotesis yang diajukan adalah sebagai berikut :

H1 : diduga pemberdayaan perempuan berpengaruh positif terhadap pendapatan rumah tangga $\mu_{1}=\mu_{2}$

$\mathrm{H} 1: \mu_{1} \neq \mu_{2}$

Model regresi linear berganda yang digunakan untuk mengetahui faktor-faktor yang mempengaruhi curahan waktu kerja wanita dalam rumah tangga;

$\dot{Y}_{2}=a+b_{1} X_{1}+b_{2} X_{2}+b_{3} X_{3}+b_{4} X_{4}+\mu$

Dimana :

$\hat{Y}_{2}=$ Curahan waktu kerja wanita

a $\quad=$ Intercept atau konstanta

$\mathrm{b}_{1}, \mathrm{~b}_{2}, \mathrm{~b}_{3}, \mathrm{~b}_{4}=$ Parameter koefisien regresi

$\mathrm{X}_{1} \quad=$ Intensitas peserta

$\mathrm{X}_{2} \quad=$ Jumlah anggota keluarga

$\mathrm{X}_{3} \quad=$ Umur ibu rumah tangga

$\mathrm{X}_{4} \quad=$ Tingkat pendidikan ibu rumah tangga

$=$ error term (koefisien error) 
Tabel 1. Indikator keluarga sejahtera berdasarkan ketetapan BKKBN

\begin{tabular}{|c|c|}
\hline Indikator & Kriteria \\
\hline \multicolumn{2}{|l|}{ Klasifikasi Kebutuhan Dasar Keluarga (Basic Needs) } \\
\hline Pada umumnya makan 2x sehari atau lebih & Keluarga Sejahtera I \\
\hline $\begin{array}{l}\text { Anggta keluarga memiliki pakaian yang berbeda untuk dirumah, } \\
\text { bekerja/sekolah dan bepergian }\end{array}$ & $\begin{array}{l}\text { Jika tidk dapatt memenuhi satua } \\
\text { atau lebih dari } 6 \text { indikatr KS-I }\end{array}$ \\
\hline Rumah yang ditempati keluarga mempunyai atap, lantai dan & maka termasuk ke dalam \\
\hline dinding yang baik & \\
\hline \multicolumn{2}{|l|}{ Bila ada anggota keuarga yang sakit di bawa ke sarana kesehatan } \\
\hline \multicolumn{2}{|l|}{ Bila pasangan usia subur ingin ber KB pergi ke sarana pelayanan } \\
\hline \multicolumn{2}{|l|}{ kontrasepsi } \\
\hline \multicolumn{2}{|l|}{ Semua anak umur 7-15 tahun dalam keluarga bersekolah } \\
\hline \multicolumn{2}{|l|}{ Klasifikasi Kebutuhan Psikologis (Pshycological Needs) Keluarga } \\
\hline Pada umumnya anggota keluarga melaksanakan ibadah sesuai & Keluarga Sejahtera II \\
\hline dengan agama dan kepercayaan mmasing-masing & Jika tidak dapat memenuhi \\
\hline Paing kurang sekali seminggu seluruh keluarga makan & satuatau leih dari 8 indikator KS- \\
\hline $\begin{array}{l}\text { daging/1kan/telur } \\
\text { Seluruh anggota keluarga memperoleh paling kurang satu stel }\end{array}$ & $\begin{array}{l}\text { II maka termasuk Ke dalam } \\
\text { Keluarga Sejahtera I }\end{array}$ \\
\hline pakaian baru dalam setahun & \\
\hline \multicolumn{2}{|l|}{ Luas lantai rumah aling kurang $8 \mathrm{~m} 2$ untuk setiappenghuni rumah } \\
\hline \multicolumn{2}{|l|}{$\begin{array}{l}\text { Tiga bulan terakhir keluarga dalam keadaan sehat sehingga dapat } \\
\text { melaksanakan yugas/fungsi masing-masing }\end{array}$} \\
\hline \multicolumn{2}{|l|}{$\begin{array}{l}\text { Ada seorang atau lebih anggota keluarga yang bekerja untuk } \\
\text { memperoleh penghasilan }\end{array}$} \\
\hline \multicolumn{2}{|l|}{ Seluruh anggota keluarga umur 10-60 bisa baca tulisan latin } \\
\hline \multicolumn{2}{|l|}{$\begin{array}{l}\text { Pasangan usia subur dengan anak dua atau lebih menggunakan } \\
\text { alat/obat kontrasepsi }\end{array}$} \\
\hline \multicolumn{2}{|c|}{ Klasifikasi Kebutuhan Pengembangan (Developmental Needs) Dari Keluarga } \\
\hline Keluarga berupaya meningkatkan pengetahuan agama & Keluarga Sejahtera III \\
\hline $\begin{array}{l}\text { Sebagian penghasilan keluarga di tabung dalam bentuk uang atau } \\
\text { barang }\end{array}$ & $\begin{array}{l}\text { Jika tidak dapat memenuhi satu } \\
\text { atau lebih dari } 5 \text { indikator KS-III }\end{array}$ \\
\hline $\begin{array}{l}\text { Kebiasaan keluarga makan bersama paing kurang seminggu sekali } \\
\text { dimanfaatkan untuk berkomunikasi }\end{array}$ & $\begin{array}{l}\text { mka termasuk ke dalam Keluarga } \\
\text { Sejahtera II }\end{array}$ \\
\hline \multicolumn{2}{|l|}{$\begin{array}{l}\text { Keluarga ikut dalam kegiatan masyarakat di lingkungan tempat } \\
\text { tinggal }\end{array}$} \\
\hline \multicolumn{2}{|l|}{ Keluarga memperoleh informasi dan surat } \\
\hline \multicolumn{2}{|l|}{ kabar/majalah/radio/tv/internet } \\
\hline \multicolumn{2}{|l|}{ Klasifikasi Aktualisai Diri (Self Esteem) Keluarga } \\
\hline Keluarga secara teratur dengan seukarela memberkan sumbangan & Keluarga Sejahtera III Plus \\
\hline materi untuk kegiatan sosial & Jika tidak dapat memenuhi satu \\
\hline Ada anggota keluarga yang aktif sebagai pengurus perkumpulan & atau lebih dari dua indikator \\
\hline sosial/yayasan/institusi masyarakat & $\begin{array}{l}\text { KS=III Plus, maka termasuk ke } \\
\text { dala Keluasga Sejahtera III }\end{array}$ \\
\hline
\end{tabular}

Sumber: BKKBN, 2010

Hipotesis kedua yang diajukan untuk melihat dampak pemberdayaan perempuan pada KWT, terhadap curahan waktu kerja wanita, yaitu;

$\mathrm{H} 2$ : diduga pemberdayaan perempuan berpengaruh positif terhadap curahan waktu kerja wanita $\mu_{1}=\mu_{2}$

$\mathrm{H} 2: \mu_{1} \neq \mu_{2}$
Untuk melihat faktor-faktor yang mempengaruhi konsumsi pangan rumah tangga, menggunakan model regresi linear berganda sebagai berikut;

$\hat{Y}_{3}=a+b_{1} X_{1}+b_{2} X_{2}+b_{3} X_{3}+b_{4} X_{4}+\mu$

Dimana :

$\mathrm{Y}_{3}=$ Konsumsi rumah tangga

a

$=$ Intercept atau konstanta

$\mathrm{b}_{1}, \mathrm{~b}_{2}, \mathrm{~b}_{3}, \mathrm{~b}_{4} \quad=$ Parameter koefisien regresi

$\mathrm{X}_{1} \quad=$ Intensitas peserta

$\mathrm{X}_{2} \quad=$ Jumlah anggota keluarga 
$\mathrm{X}_{3} \quad=$ pendapatan rumah tangga

$\mathrm{X}_{4} \quad=$ Tingkat pendidikan ibu rumah tangga

$\mu \quad=$ error term (koefisien error)

Hipotesis ketiga yang diajukan untuk melihat dampak pemberdayaan perempuan pada KWT, terhadap konsumsi rumah tangga, yaitu;

H3 : diduga pemberdayaan perempuan berpengaruh terhadap konsumsi pangan rumah tangga $\mu_{1}=\mu_{2}$

H3 : $\mu_{1} \neq \mu_{2}$

\section{HASIL}

Rumah tangga Kelompok Wanita Tani di Kota Prabumulih, memiliki karakteristik yang cukup bervariasi, hal tersebut dapat dilihat dari karakteristik berikut, berdasarkan tabulasi data pada Tabel 2 .

Selain karakterisktik umum seperti pada Tabel 2, dilakukan juga beberapa tabulasi pada karakteristik perilaku ekonomi rumah tangga, yaitu curahan waktu kerja dan pengeluaran rumah tangga (Tabel 3) dan tingkat pendapatan (Tabel 4).

\section{Tingkat Kesejahteraan Rumah Tangga}

Dari penelitian yang dilaksanakan, menunjukkan tingkat kesejahteraan rumah tangga peserta Kelompok Wanita Tani (Tabel 5). Berdasarkan tabel di atas menunjukkan, berdasarkan indikator Keluarga Sejahtera yang ditetapkan BKKN, Keluarga Sejahtera I sebanyak 25\%\%, sebanyak $35 \%$ rumah tangga Kelompok Wanita Tani berada pada kategori Keluarga Sejahteraan II. Sedangkan Keluarga Sejahteraan III sebanyak $25 \%$, dan pada kategori Keluarga Sejahtera III-Plus sebanyak $15 \%$.

\section{Perilaku Ekonomi Rumah Tangga}

Dalam penelitian ini, untuk melihat pperilaku ekonomi rumah tangga, dilakukan pendekatan terhadap tiga aktivitas ekonomi rumaah tangga, yaitu dari sisi pendapatan, curahan waktu kerja dan konsumsi pangan (Tabel 6).

Tabel 2. Karakteristik rumah tangga anggota kelompok wanita tani di Prabumulih

\begin{tabular}{|c|c|c|}
\hline Variabel & Jumlah & Persentase $\%$ \\
\hline \multicolumn{3}{|l|}{ Intensitas dalam KWT } \\
\hline - Aktif & 47 & 78,33 \\
\hline - Tidak Aktif & 13 & 21,67 \\
\hline \multicolumn{3}{|c|}{ Tingkat Pendapatan Rumah Tangga/bulan } \\
\hline-1 juta -3 juta & 18 & 30,00 \\
\hline-4 juta -6 juta & 36 & 60,00 \\
\hline-7 juta -10 juta & 6 & 10,00 \\
\hline \multicolumn{3}{|c|}{ Kelompok Umur Anggota KWT } \\
\hline$-26-30$ & 6 & 10,00 \\
\hline$-31-40$ & 19 & 31,67 \\
\hline$-41-50$ & 25 & 41,67 \\
\hline$->50$ & 10 & 16,66 \\
\hline \multicolumn{3}{|c|}{ Tingkat Pendidikan Formal } \\
\hline - SMP & 7 & 11,67 \\
\hline SMA & 37 & 61,67 \\
\hline S1 & 15 & 25,00 \\
\hline$-\quad S 2$ & 1 & 1,66 \\
\hline \multicolumn{3}{|c|}{ Jumlah Anggota Keluarga (orang) } \\
\hline$-\quad 1-2$ & 5 & 8,33 \\
\hline $3-5$ & 39 & 65,00 \\
\hline $6-8$ & 14 & 23,33 \\
\hline- & 2 & 3,34 \\
\hline
\end{tabular}

Sumber: Data primer diolah, 2019 
Tabel 3. Curahan waktu kerja rumah tangga kelompok wanita tani di Prabumulih

\begin{tabular}{|c|c|c|c|c|c|c|}
\hline \multirow[t]{2}{*}{ Jenis Kegiatan } & \multicolumn{4}{|c|}{ Rata-rata Curahan Waktu Kerja (HOK/th) } & \multirow[t]{2}{*}{ Total } & \multirow{2}{*}{$\begin{array}{c}\text { Persentase } \\
(\%)\end{array}$} \\
\hline & Pria & $\%$ & Wanita & $\%$ & & \\
\hline Non Usahatani & 206,827 & 59,24 & 105,191 & 37,86 & 312,018 & 49.77 \\
\hline Usahatani & 142,307 & 40,76 & 172,651 & 62,14 & 314,958 & 50,23 \\
\hline Jumlah & 349,134 & 100 & 277,842 & 100 & 626,976 & 100 \\
\hline
\end{tabular}

Sumber: Data Primer diolah, 2019

Tabel 4. Rata-rata pengeluaran rumah tangga kelompok wanita tani di Prabumulih

\begin{tabular}{|c|c|c|}
\hline Jenis Pengeluaran & Jumlah (Rp/th) & Persentase (\%) \\
\hline Konsumsi Pangan & 29.025 .131 & 48,71 \\
\hline Konsumsi Non Pangan & 23.495 .399 & 39,43 \\
\hline Tabungan & 7.067 .093 & 11,86 \\
\hline Jumlah & 59.587 .623 & 100,00 \\
\hline
\end{tabular}

Sumber: Data primer diolah, 2019

Tabel 5. Tingkat kesejahteraan keluarga peserta kelompok wanita tani, di Prabumulih

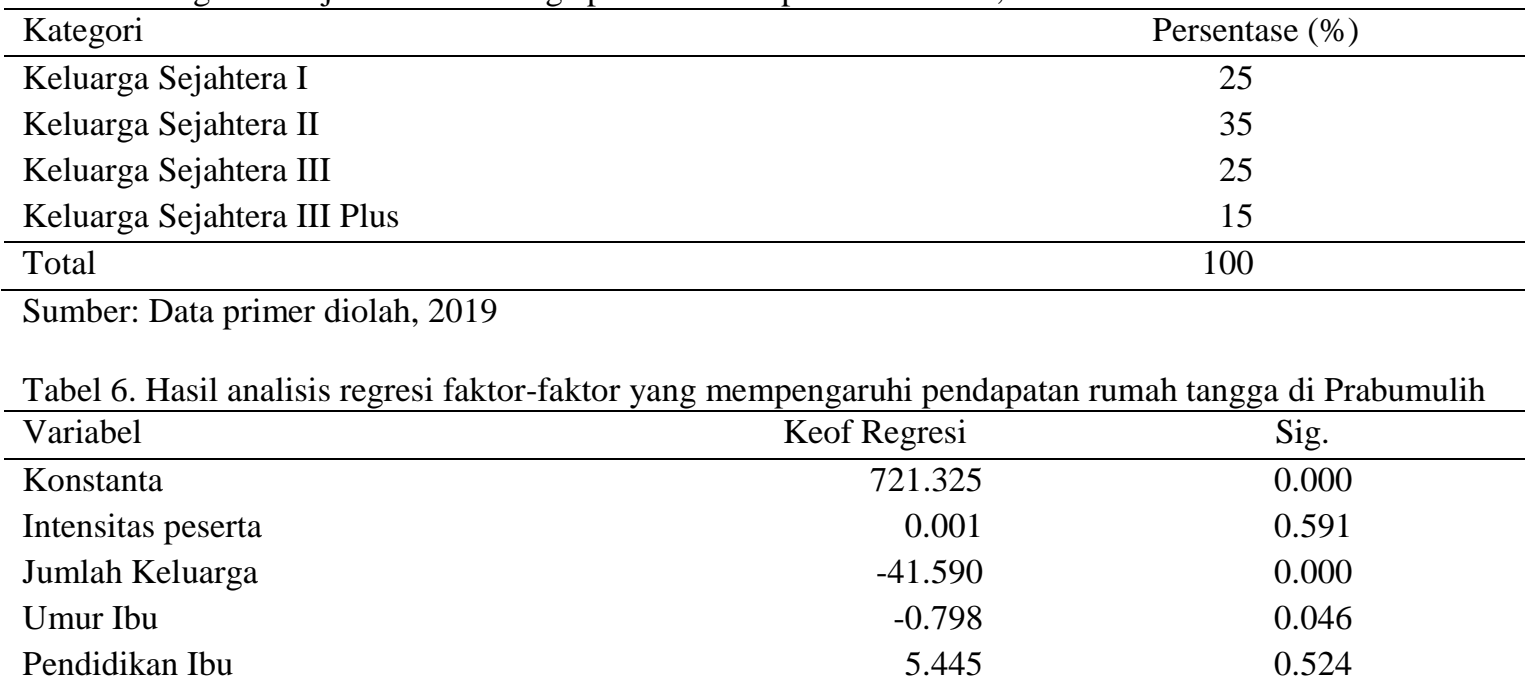

Sumber: Data primer diolah, 2019

Dari Tabel 6, diperoleh persamaan:

$Y=721.325+0,001 X_{1}-41,590 X_{2}-0,798 X_{3}+5,445 X_{4}$

\section{PEMBAHASAN}

\section{Tingkat Kesejahteraan Rumah Tangga}

Berdasarkan tabulasi data yang diperoleh, menunjukka jika dilihat berdasarkan indikator yang ditetapkan BKKBN, sebagian besar rumah tangga peserta Kelompok Wanita Tani di Prabumulih berada pada kategori Keluarga Sejahtera II (KS II), yaitu sebesar 35\% . Hal ini menunjukkan sebagian besar rumah tangga sudah dapat memenuhi kebutuhan dasarnya (basic needs) dan kebutuhan psikologisnya (physicological needs). Terlihat dari sebagian besar rumah tangga selain telah memenui kebutuhan sandang, pangan dan papan anggota keluarganya, juga telah mampu memenuhi kebutuhan psikologis seperti beribadah, keehatan, dan pendidikan dasar.

Selain itu, ada sebanyak 25\% rumah tangga yang berada pada kategori Keluarga Sejahtera III. Dimana pada kategori ini rumah tangga sudah berada pada kondisi telah dapat memenuhi kebutuhannya, dan mulai melakukan kegiatan-kegiatan untuk pengembangan kemampuan anggota rumah tangga dalam masyarakat. Bahkan terdapat sebanyak $15 \%$ rumah tangga yang sudah berada pada kategori Keluarga Sejahtera III Plus. Pada kategori ini, rumah tangga sudah mulai menunjukkan aktualisasi diri dalam masyarakat yang anggota rumah tangga sudah berperan aktif dalam kegiatan dan pembangunan di masyarakat sekitar, serta sduah mampu memberikan pengaruh pada 
masyarakat sekitar. Hal ini menunjukkan bahwa anggota Kelompok Wanita Tani di Prabumulih tidak hanya berasal dari rumah tangga dengan kategori kesejahteraan yang rendah. Dengan demikian, proses transfer ilmu dan program pemberdayaan pada Kelompok Wanita Tani di Prabumulih memiliki kemugkinan keberhasilan yang cukup tinggi, dikarenakan keberagaman latar belakang pesertanya.

Hasil tersebut mendukung hasil penelitian yang telah dilakukan oleh Nurmanaf (2007), yang menggambarkan bahwa pendapatan rumah tangga petani tidak dapat hanya mengandalkan dari kegiatan usahatani. Bahwa sektor non pertanian berperan penting dalam tingkat kesejahteraan rumah tangga petani. Kegiatan non usahatani yang paling banyak dan memberikan hasil yang sigifikan adalah dari kegiatan berdagang. Bahwa tingkat kesejahteraan rumah tangga petani juga berjalan searah dengan tingkat pendapatan rumah tangga petani (Sari et al., 2014)

\section{Perilaku Ekonomi Rumah Tangga}

Dari hasil analisis regresi yang dilakukan, dapat dilihat faktor-faktor yang mempengaruhi perilaku ekonomi rumah tangga dari sisi pendapatan, curahan waktu kerja dan pengeluaran. Hal yang sama ditujukkan pada hasil peelitian yang dilakukan Mariyanto (2015), yang menyatakan bahwa terdapat keterkaitan antara keputusan produksi, alokasi curahan waktu kerja dan keputusan konsumsi dalam sistem usahatani lahan kering.

Dalam penelitian yang dilakukan oleh Subianto (2007), bahwa perilaku konsumen rumah tangga dipengaruhi oleh dua faktor utama, yaitu faktor internall dan eksternal. Faktor internal diantaranya; motivasi, kepribadian, pendapatan. Sedangkan faktor ekternal seperti; kelompok rujukan, kelas sosial, budaya. Pada penelitian ini, faktorfaktor yang berpengaruh terhadap perilaku konsumen dapat dilihat pada Tabel 8 .

Pada Tabel 6, dari model regresi didapat signifikansi $\mathrm{F}$ pada Tabel Anova adalah sebesar $0,000(<0,05)$. Hal ini menunjukkan bahwa variabel bebas (intensitas peserta, jumlah anggota keluarga, umur ibu rumah tangga, dan tingkat pendidikan ibu) berpengaruh nyata terhadap variabel bebas (pendapatan rumah tangga). Secara parsial, variabel bebas dalam penelitian, ada yang berpengaruh nyata dan ada yang tidak berpengaruh nyata terhadap variabel terikat. Hasil estimasi menunjukkan bahwa variabel jumlah anggota keluarga dan umur ibu berpengaruh nyata terhadap pendapatan rumah tangga. Namun, variabel intensitas peserta dan tingkat pendidikan ibu berpengaruh tidak nyata terhadap pendapatan rumah tangga. Dari hasil ini menunjukkan bahwa intensitas peserta, dalam hal ini keaktifan peserta dalam kegiata Kelompok Wanita Tani belum memberikan dampak secara langsung terhadap pendapatan rumah tangga. Hal ini terjadi karena keikutsertaan ibu dalam Kelompok Wanita Tani belum memberikan penghasilan dari sisi ekonomis secara langsung yang dapat menambah pendapatan rumah tangga secara signifikan.

Kondisi ini berbeda dengan penelitian yang dilakukan Ervinawati (2015) yang menyimpulkan bahwa peranan wanita tani sangat besar dalam memberikan kontribusinya terhadap keluarga, bukan saja sebagai penunjang, bahkan sebagian besar sebagai tulang punggung keluarga dalam memenuhi kebutuhan ekonomi keluarga. Di antara faktor yang menyebabkan perbedaan pada penelitian ini, adalah daerah domisili peserta kelompok wanita tani. Pada daerah pedesaan umumnya kegiatan usahatani menjadi sumber pendapatan utama, sehingga adanya kelompok wanita tani menjadi pendorong untuk meningkatkan pendapatan dari kegiatan usahatani. Namun, pada daerah perkotaan, selain usahatani banyak alternatif usaha yang dilakukan rumah tangga untuk menjadi sumber pendapatan, misal dagang ataupun jasa angkutan, dan lain lain. Sehingga kegiatan kelompok wanita tani lebih diarahkan pada kegiatan usahatani subsisten.

Seperti halnya pada hasil penelitian yang dilakukan oleh Rochaeni (2005), bahwa 
jumlah anggota rumahtangga berpengaruh positif dan memberikan respon yang inelastis terhadap konsumsi. Sedangkan pendapatan disposibel berpengaruh positif dan memberikan respon inelastis terhadap konsumsi non pangan, dan pendidikan, tetapi memberikan respon elastis terhadap investasi produksi.

Tabel 7. Hasil analisis regresi faktor-faktor yang mempengaruhi curahan waktu kerja rumah tangga di Prabumulih

\begin{tabular}{lcc}
\hline Variabel & Keof Regresi & Sig. \\
\hline Konstanta & 326.445 & 0.000 \\
Intensitas peserta & 0.017 & 0.001 \\
Jumlah Keluarga & -53.230 & 0.524 \\
Umur Ibu & -0.198 & 0.021 \\
Pendidikan Ibu & 2.143 & 0.047 \\
\hline
\end{tabular}

Sumber: Data primer diolah, 2019.

Dari Tabel 7, diperoleh persamaan;

$\mathrm{Y}=326,445+0,017 \mathrm{X}_{1}-53,230 \mathrm{X}_{2}-0,198 \mathrm{X}_{3}+2,143 \mathrm{X}_{4}$

Tabel 8. Hasil analisis regresi faktor-faktor yang mempengaruhi konsumsi rumah tangga di Prabumulih

\begin{tabular}{lrl}
\hline Variabel & Keof Regresi & Sig. \\
\hline Konstanta & 642.125 & 0.000 \\
Intensitas peserta & 0.006 & 0.001 \\
Jumlah Keluarga & 21.783 & 0.027 \\
Pendapatan & 0.941 & 0.037 \\
Pendidikan Ibu & 7.159 & 0.134 \\
\hline
\end{tabular}

Sumber: Data primer diolah, 2019

Dari Tabel 8, diperoleh persamaan;

$Y=642,125+0,006 X_{1}+21,783 X_{2}+0,941 X_{3}+7,159 X_{4}$

Dari model regresi kedua yang terlihat pada Tabel 7, juga menunjukkan bahwa variabel bebas (intensitas peserta, jumlah anggota keluarga, umur ibu rumah tangga dan tingkat pendidikan ibu) secara bersamaan berpengaruh nyata terhadap curahan waktu kerja rumah tangga. Sedangkan secara parsial seluruh variabel independen berpengaruh nyata terhadap curahan waktu kerja, kecuali variabel jumlah anggota keluarga. Hal ini dikarenakan pada rumah tangga Kelompok Wanita Tani, sebagian besar masih memiliki anak yang berada pada usia sekolah, sehingga yang bekerja dalam keluarga hanya ayah dan ibu. Hal ini mengakibatkan banyaknya jumlah anggta keluarga tidak berpengaruh terhadap curahan waktu kerja. Pada model regresi yang kedua juga menunjukkan bahwa, intensitas peserta pada Kelompok Wanita Tani berpengaruh nyata terhadap curahan waktu kerja, terutama curahan waktu kerja wanita. Karena ada waktu-waktu yang sebelum menjadi anggota kelompok tani hanya digunakan untuk istirahat, dapat dimanfaatkan untuk kegiatan-kegiatan kelompok, baik secara bersama atau mandiri di rumah masing-masing. Sehingga banyak kegiatan produktif yang dilakukan oleh ibu rumah tangga.

Sedangkan pada model regresi yang ketiga (Tabel 8), terlihat bahwa variabel bebas (intensitas peserta, jumlah anggota keluarga, pendapatan dan pendidikan ibu) secara bersama-sama berpengaruh nyata terhadap variabel terikat (pengeluaran rumah tangga). Sedangkan secara parsial, kecuali variabel pendidikan ibu, seluruh variabel berpengaruh nyata terhadap pengeluaran rumah tangga. Salah satu penyebab hal ini dikarenakan lebih dari separuh $(61,67 \%)$ ibu memiliki tingkat pendidikan yang sama, yaitu SMA/sederajat, yang sebagian besar merupakan ibu rumh tangga. Sehingga, tidak banyak memerlukan pengeluaran diluar pengeluaran sehari-hari.

Hal tersebut sama halnya dengan hasil penelitian yang dilakukan Asmarantaka (2007), yang menunjukkan adanya salig keterkaitan untuk keputusan konsumsi, 
produksi (pendapatan), penggunaan tenaga kerja dan pupuk, biaya pendidikankesehatan, dan tabungan dalam rumah tangga petani desa pangan di Provinsi Lampung.

\section{KESIMPULAN}

Berdasarkan penelitian yang dilakukan, maka dapat disimpulkan bahwa;

1. Sebagian besar rumah tangga Kelompok Wanita Tani di Prabumulih berada pada kategori Keluarga Sejahtera II yaitu sebanyak 35\%. Sedangkan pada Keluarga Sejahtera I dan Keluarga Sejahtera III masingmasing sebanyak $25 \%$, dan sebayak $15 \%$ berada pada kategori Keluarga Sejahtera III Plus.

2. Dari ketiga model yang di analisis, intensitas peserta dalam Kelompok Wanita Tani di Prabumulih baik secara bersama-sama dengan variabel lain dalam persamaan berpengaruh nyata terhadap pendapatan, curahan waktu kerja dan pengeuaran rumah tangga. Namun secara parsial, variabel intensitas peserta berpengaruh nyata dan positif sebesar 0,017 pada persamaan curahan waktu kerja dan sebesar 0,006 pada persamaan pengeluaran rumah tangga. Sedangkan pada persamaan pendapatan, secara parsial variabel intensitas peserta tidak berpengaruh nyata. Dengan demikian dapat dikatakan bahwa pemberdayaan perempuan dalam hal ini pada Kelompok Wanta Tani berpengaruh signifikan terhadap perilaku ekonomi curahan waktu kerja dan pengeluaran, tetapi tidak signifikan terhadap pendapatan pada rumah tangga di Prabumulih

\section{UCAPAN TERIMA KASIH}

Sehubungan dengan terlaksananya penelitian ini, peneliti mengucapkan terimakasih atas kepercayaan dan kesempatan yang diberikan phak DRPM
Dikti dalam kelompok Peneitian Dosen Pemula (PDP) tahun anggaran 2019. Juga kepada Ketua dan seluruh sivitas akademik STIE Prabumulih atas bantuan dan dukungannya dalam pelaksanaan penelitian hingga saat ini, Juga kepada suami dan anak-anak yang menjadi penyemangat dan pendukung terbesar dalam setiap kegiatan.

\section{DAFTAR PUSTAKA}

Anggrainie R. 2014. Analisis curahan waktu kerja anggota rumah tangga petani dan pengaruhnya terhadap perilaku ekonomi rumah tangga petani karet di Prabumulih. Belitung. Universitas Bangka Belitung. Jurnal Buana Agribisnis. 1(1):1-12

Anggrainie R. 2011. Analisis perilaku ekonomi rumah tangga petani karet di Prabumulih. Indralaya. Jurnal Agripita. 1(2):103-112.

Asmarantaka R. 2007. Analisis ekonomi rumah tangga petani tanaman pangan di Provinsi Lampung. Jurnal Agribisis dan Ekonomi Pertanian. 1(1):1-18

Badan Pusat Statistik. 2017. Kota Prabumulih Dalam Angka. Prabumulih. BPS Kota Prabumulih.

Ervinawati V. 2015 Peranan kelompok wanita tani perdesaan dalam menunjang pendapatan keluarga (di Dusun Beringin Desa Sungai Regas Kecamatan Sungai Kakap, Kabupaten Kubu Raya Provinsi Kalimantan Barat). Pontianak. Universitas Tanjungpura Pontianak [Tesis].

Fatmawati, Vera N. 2018. Peran kelompok wanita tani dalam meningkatkan pendapatan keluarga (studi kasus pada kelompok wanita tani putri mandiri Desa Kebanggan Kecamatan Sumbang). [Skripsi] Purwokerto. IAIN Purwokerto.

Husin L, Wulansari. 2011. Perilaku ekonomi rumah tangga petani karet di Prabumulih dalam alokasi tenaga kerja, produksi dan konsumsi. Palembang. Universitas Sriwijaya. Laporan Penelitian I-MHERE. 
Kuncoro, Amin, Kadar. 2016. Pengaruh pemberdayaan perempuan dan peningkatan sumberdaya ekonomi keluarga. Surakarta. Buana Gender. 1(1):13-25.

Kusnadi N. 2005. Perilaku Ekonomi Rumah Tangga Petani dalam Pasar Persaingan Tidak Sempurna di Beberapa Provinsi di Indonesia. [Disertasi] Bogor. Institut Pertanian Bogor.

Mariyanto, Joko. 2015. model ekonomi rumah tangga pertanian lahan kering di Kabupaten Karanganyar Provinsi Jawa Tengah. Habitat. 26(2):108-118.

Minarni, Endang. 2017. Pemberdayaan kelompok wanita tani melalui optimalisasi pemanfaatan pekarangan dengan budidaya sayuran organik dataran rendah berbasis kearifan lokal dan berkelanjutan. Jurnal Pengabdian dan Pemberdayaan Masyarakat. 1(2):147-154.

Nurmanaf, Rozany A. 2007. Karakteristik rumah tangga petani berlahan sempit: struktur dan stabilitas pendapatan di wilayah berbasis lahan sawah tadah hujan (kasus di Propinsi Jawa Tengah dan Jawa Timur). Bogor. Pusat Penelitian dan Pengembangan Sosial Ekonomi.

Rochaeni S, Lokollo. 2005. Faktor-faktor yang mempengaruhi keputusan ekonomi rumah tangga petani di kelurahan setugede Kota Bogor. Bogor. Jurnal Agro Ekonomi. 23(2):133-158.
Rohmah W, Suryatin, Hartono. 2014. Analisis pendapatan dan tingkat kesejahteraan rumah tangga petani tebu tanam dan keprasan di Kabupaten Bantul. Agro Ekonomi. Jurnal Sosial Ekonomi Pertanian. UGM. 24(1):54-65.

Sari DK, Haryono, Rosanti. 2014. Analisis pendapatan dan tingkat kesejahteraan rumah tangga petani jagung di Kecamatan Natar Kabupaten Lampung Selatan. Jurnal Ilmu-ilmu Agribisnis. 2(1):64-70.

Subianto, Totok. 2007. Studi tentang perilaku konsumen beserta impilkasinya terhadap keputusan pembelian. Malang. Jurnal Ekonomi Medernisasi. 3(3):165182.

Sugiyono. 2013. Metode Penelitian Kuantitatif, Kualitatif dan R\&D. Bandung. Alfabeta.

Sulistyani AT. 2014. Kemitraan dan model model pemberdayaan. Graha Ilmu. Yogyakarta.

Undang-Undang Republik Indonesia No. 52 tahun 2009 tentang Perkembangan Kependudukan dan Pembangunan Keluarga.

Warga, I Made. 2016. Pengaruh pendapatan anggota usaha kelompok wanita tani satya wacana terhadap pendapatan keluarga di Banjar Dinas Tukad Tiis Desa Seraya Timur Kecamatan Karangasem. Jakarta. Jurnal Program Studi Pedidikan Ekonomi. 6(1):1-10. 